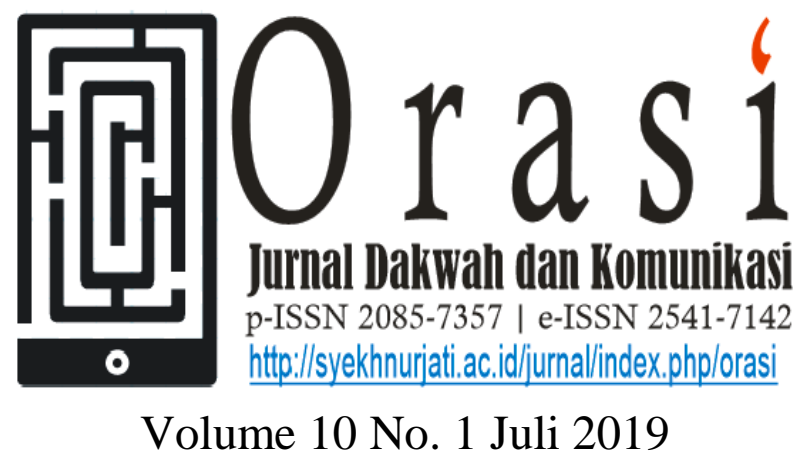

\title{
AGAMA DAN BUDAYA POPULAR
}

\author{
Cartono \\ Jurusan Komunikasi dan Penyiaran Islam, IAIN Syekh Nurjati Cirebon \\ Jl. Perjuangan By Pass Sunyaragi Cirebon \\ e-mail: cartonopr@gmail.com
}

\begin{abstract}
The existence of a popular culture that has plagued the public is in line with the soaring development of information technology and social networking media that have now entered the private dimension in the spaces of the Muslim community in Indonesia. The existence of social media has a strong connection with religion. Media and social networks have a profound impact on the life and religious attitude of the Indonesian people. And the problem that comes is about how people carry out Islamic values that they understand when compared to the phenomenon of modernization. This phenomenon triggers various kinds of advanced phenomena which demand redefinition of ideal Islamic life. In its use, many of them often ignore religious and social values. The crime rate that starts from social media is increasing, as if to emphasize the use of social media has an impact on the implementation of social and religious values, especially the people of Indonesia. In phenomena, culture in the global era leads to secular values which have a great influence on the development of religious souls. In conjunction with the religious soul the influence of globalization can be seen through relations with changing attitudes, for example, is the loss of the handle of life that is referenced from the traditions of the people and sourced from religious teachings.
\end{abstract}

Keywords: Religion, Popular Culture

\section{ABSTRAK}

Keberadaan budaya popular yang telah menjangkiti masyarakat sejalan melonjaknya perkembangan teknologi informasi dan media jejaring sosial yang kini telah masuk pada dimensi privat di ruang-ruang dalam rumah tangga masyarakat Muslim d iindonesia. Keberadaan media sosial mempunyai keterkaitan yang kokoh dengan agama. Media dan jejaring sosial sangat berdampak bagi kehidupan dan sikap keberagamaan masyarkat Indonesia. Dan 
persoalan yang datang adalah tentang bagaimana masyarakat menjalankan nilanilai Islam yang dipahaminya bila disandingkan dengan fenomena modernisasi. Fenomena tersebut memicu berbagai macam fenomena lanjutan yang menuntut pendefinisian ulang bagi kehidupan Islam yang ideal. Dalam penggunaannya banyak diantara mereka sering mengabaikan nilai-nilai agama dan sosial. Tingkat kriminalitas yang bermula dari sosial media semakin meningkat, seakan menegaskan penggunaan sosial media memiliki dampak terhadap pelaksanaan nilai sosial dan agama terutama masyarakat Indonesia. Secara fenomena, kebudayaan pada era global menuju kepada nilai-nilai sekuler yang besar pengaruhnya pada perkembangan jiwa keagamaan. Dalam hubungannya dengan jiwa keagamaan pengaruh globalisasi dapat dilihat lewat hubungan dengan perubahan sikap, misalnya adalah hilangnya pegangan hidup yang dirujuk dari tradisi masyarakat dan bersumber dari ajaran agama.

Kata Kunci : Agama, Budaya Popular

\section{Pendahuluan}

Seiring dengan perkembangan zaman, dari sesuatu yang sifatnya sederhana hingga pada sesuatu kompleks. Proses globalisasi berperan dalam melakukan perubahan pada prilaku masyarakat. dan kini menjadi alat kapitalisme dalam mendistribusikan akan sesuatu yang berbau budaya atau sering disebut dengan istilah budaya populer. Sebenarnya globalisasi merupakan tanda dari sebuah keniscayaan yang menghadirkan berbagai dampak, entah itu positif ataupun negatif. Proses globalisasi berjalan mengarah kepada integrasi, akan tetapi di sisi lain globalisasi juga bendampak pada kehidupan menuju disintegrasi. Hal tersebut terlihat pada terintegrasinya referensi agama dan budaya lokal yang mulai tergeser oleh budaya luar, akan tetapi karena proses integrasi tersebut memicu timbulnya disintegrasi sebab referensi agama dan budaya lokal ternyata belum mampu menahan derasnya arus globalisasi.

Dalam konteks agama dimana mayoritas penduduknya adalah muslim, arus globalisasi membawa politik nasional ke pusaran gelombang demokratisasi ketiga di dunia dan menerjang Indonesia lewat gerakan reformasi. Efek dari globalisasi dengan datangnya budaya popular ke
Indonesia, berbagai macam aspek kehidupan masyarakat indonesia mengalami redefinisi dan diferensiasi yang terjadi secara meluas yang menggambarkan sifat relatif akan suatu praktik sosial, termasuk praktik agama itu sendiri. Keterkaitan Islam dan budaya di Indonesia pada pada hakikatnya saling berkaitan dan sulit dipisahkan. Sejarah menunjukan bahwa Islam disambut dengan baik masyarakat indonesia sebab Islam dengan nilai-nilainya yang dapat sejalan ke dalam budaya tanpa menghilangkan nilai budaya itu sendiri. Globalisasi telah meredefinisi ajaran Islam kedalam bermacam aspek kehidupan. Indonesia yang mengalami perkembangan secara gradual terkait dengan demokratisasi berkembangnya sektor ekonomi dan teknologi informasi. Namun, yang menjadi permasalahanya adalah mengenai seperti apa masyarakat indonesia menjalankan nila-nilai agama apabila disandingkan pada fenomena modernisasi. Fenomena tersebut ada dari berbagai macam fenomena lanjutan yang memaksa pendefenisian ulang dalam kehidupan ajaran Islam. Hal lain yang perlu dikaji adalah tentang keberadaan budaya popular yang telah menjangkiti masyarakat sejalan melonjaknya perkembangan turunan teknologi informasi yaitu media jejaring 
sosial yang telah masuk pada dimensi privat di ruang-ruang dalam rumah tangga masyrakat muslim di indonesia.

\section{Hasil dan Pembahasan}

\subsection{Fakta Agama Dan Budaya Popular}

Era global diikuti oleh proses kehidupan mendunia, kamajuan IPTEK terutama dalam bidang komunikasi dan menjadi pemicu terjadinya lintas budaya. Dalam hubunganya dengan jiwa keagamaan, mungkin dampak globalisasi tersebut dapat dilihat melalui keterkaitanya dengan perubahan sikap. Jalaluddin Rahmat, Terjadinya perubahan sikap tersebut disebabkan persamaan persepsi pada diri seseorang atau masyarakat terhadap suatu hal. Hal ini berarti bahwa jika dampak globalisasi dengan segala muatannya di nilai baik oleh individu maupun masyarakat, maka masyarakat akan menerimanya (1996:77).

Secara fenomena, kebudayaan popular mengarah kepada nilai-nilai sekuler yang besar dampaknya terhadap perkembangan jiwa keagamaan. walaupun dalam sisi-sisi tertentu kehidupan tradisi keagamaan terlihat meningkat dalam kesemarakannya. Akan tetapi dalam kehidupan masyarakat global yang cenderung sekuler mungkin akan ada dampaknya kepada pertumbungan jiwa keagamaannya. paada situasi tersebut, dapat saja terjadi berbagai macam kemungkinan. Menurut Tonny ada beberapa hal Pertama, mereka tidak larut dalam penggunaan yang berlebihan terhadap rekayasa teknologi dan masih berpedoman pada nilai - nilai keagamaan, kemungkinan akan lebih meyakini tentang kebenaran agama. Kedua, kelompok kurang tersentuh nilai-nilai ajaran agama akan mengalami kekosongan jiwa, kelompok ini kesulitan menentukan pilihan dalam menentramkan gejolak dalam jiwanya (2004:62).
Budaya popular bisa dibilang dengan budaya massa, merupakan budaya yang dibuat untuk keperluan massa, serta mengikuti alur produksi massa. Budaya popular menggambarkan akan kebaradaan budaya nonpupuler antonimnya, dimana dibangun oleh pendekatan nonpopular yang sering disebut sebagai budaya yang luhur.Terkait dengan hal tersebut pada perkembangannya media dan jejaring sosial di Indonesia merupakan kejadian menarik yang tidak didapatkan di negeri Muslim lain di dunia. Jumlah pemakai internet Indonesia pada tahun 2016 mencapai 132,7 juta, fakta lainnya dari Asosiasi Penyelenggara Jasa Internet Indonesia (APJII) dari hasil surveinya ada tiga (3) media sosial yang paling banyak dikunjungi oleh masyarakat indonesia.

Berdasarkan survei tersebut, pemakai Facebook berada di tingkat pertama menjadi media sosial yang paling banyak digemaripemakai internet Indonesia, yaitu dengan angka 71,6 juta pemakai (54\%). Hal tersebut sebenarnya tidak terlalu mengejutkan, mengingat hasil laporan dari We Are Social yang menempatkan Facebook menjadi media sosial dengan pemakai aktif terbanyak pada posisi kedua, setelah Black Berry Messenger (BBM) yang menjadi tingkat pertama. selanjutnya media sosial dalam berbagi foto dan video pendek media sosial Instagram denganpemakai internet Indonesia mencapai 19,9 juta (15\%). Media sosial berikutnya yang paling banyak diminati pemakai internet Indonesia adalah layanan YouTube. Dimana Layanan berbagi video ini mencapai 14,5 juta pengguna(11 $\%)$. dalam pengambilan data survei tersebut, APJII melakukan survei lapangan dan tatap muka dengan menggunakan teknik pengambilan sampel multi stage random sampling. pada survei terkait dengan penetrasi pemakai internet, APJII melibatkan sebanyak 1.200 responden, untuk survei 
prihal perilaku pemakai termasuk media sosial apa yang dikunjungi), APJII melibatkan sebanyak 2.000 responden. Besaran jumlah pemakai media dan jejaring sosial tersebut tidak diiringi penciptaan budaya agama yang bisa dijadikan sebagai budaya tandingan dari budaya luar popular.

Ekspansi budaya popular lainnya adalah lewat musik dimana masyarakat indonesia menggandrungi musik dari mancanegara. Indonesia akhir-akhir ini kedatangan konser musisi barat. Kedatangan musisi tersebut merupakan magnet bagi masyarakat yang haus hiburan. Dimana terdapat lebih dari 50 musisi luar yang melakukan konser musik di Indonesia. Rangkaian konser musik dari musisi mancanegara masih terus berlangsung ditambah dengan Gelombang musik Korea di Indonesia yang juga belum reda. kita dapat melihat bagaimana kaum muda khususnya muslim dan para wanita Muslim lengkap dengan jilbabnya dengan histeris berteriak menyambut idola mereka serta tidak ragu untuk menciumi, memeluk dan menangisi artis idolanya tersebut. Hal ini merupakan suatu fenomena menarik, disaat kebudayaan popular berkembang di komunitas masyarakat Muslim di Indonesia.

\subsection{Skema Budaya Popular}

Menurut Djokosantoso Moeljono Budaya merupakan (1) pikiran; akal budi, (2) adat istiadat, (3) sesuatu tentang kebudayaan yang telah berkembang (4) perkara yang telah menjadi habits yang telah sulit diubah. Selain itu budaya juga didefinisikan sebagai metode manusia memberikan respons terhadap lingkungannya, supaya bisa survive dan menang (2006:71). Sedangkan Populer dalam KBBI didefinisikan sebagai sesuatu yang dikenal dan disukai khalayak umum sesuai dengan apa yang dibutuhkan masyarakat pada umumnya; mudah dimengerti masyarakat, disukai dan dikagumi. Maka budaya pop atau budaya popular dapat diartikan sebagai sesuatu yang sudah berkembang kemudian menjadi kebiasaan dan disukai oleh banyak orang.

Stuart Hall mengilustrasikan budaya popularcontohnya sebagai "sebuah arena konsensus dan resistensi. Budaya popular adalah wadah dimana hegemoni muncul, dan teritorial dimana hegemoni berlangsung. John Storey Budaya popular bukan ranah dimana sosialisme, sebuah budaya sosialis yang sudah terbentuk total dandapat benarbenar diperhatikan. Akan tetapi, ini merupakan salah satu wadah dimana sosialisme memperoleh legalitas. Itulah sebabnya mengapa budaya popular menjadi sesuatu yang penting (2010:3).

Budaya popular yang dipengaruhi oleh imajinasi popular yang kini telah merasuki masyarakat Islam. Imajinasiimajinasi tersebut dibangun secara sadar oleh orang atau sekelompok orang, yaitu oleh produsen, kapitalis, dan para elit sebagai pembeda mereka dengan orang lain. Menurut Yasraf Amir Piliang dalam bukunya yang berjudul bayang-bayang Tuhan menyebutkan bahwa Agama dan Imajinasi menjelaskan bahwa imajinasi popular semacam ini dipengaruhi oleh empat ranah.Yang Pertama adalah metode berpikir popular, yakni metode berpikir jalan pintas yang penting untuk mendapatkan suatu kesenangan, bilaperlu tanpa harus berpikir. Metode berpikir tersebut mengutamakan penampilan dari pada kualitas jiwa, popularitas dari pada spiritualitas, kedangkalan dari pada kedalaman. Fakta ini dapat kita lihat seperti misalnya, menjamurnya buku dan forum seminar how to yang menjanjikan metode instan menjadi milarder, cepat pintar, dan bahkan cepat memahami Islam. Masyarakat Islam yang terjebak dengan metode berpikir budaya popular ini akan menjadi masyarakat yang nantinya akan menjadi malas berpikir, cari enak dan jalan pintas. 
Kedua, komunikasi popular. Komunikasi popular ini ditandai dengan dakwah yang dihiasi dengan imajinasi dan fantasi yang terdapat di dalam budaya popular, yakni berupa bahasa, tindakan, dan penampilan popular. Contohnya adalah dakwah Islam yang memuat unsur komedi, lawakan, banyolan yang sering tayang di TV. Bukan hanya itu saja para dai pun kini berperan menjadi bintang iklan atau superstar di depan massa penggemarnya. Masyarakat pada akhirnya dengan pasif mencontek kebiasaan, penampilan, dan gaya dai superstar idolanya serta memunculkan keinginan masyarakat untuk mengoleksi barang-barang para dai yang digemarinya. Bahkan masayarakat sampai mengincar tanda tangan. Kini para Da'i telah menjadi selebritis yang diidolakan, memanglah sah saja jika masyarakat mengidolakan seseorang akan tetapi sikap masyarakat yang berlebihan dianggap tidak etis.

Ketiga, ritual popular ini dilaksanakan dengan mengacu pada paradigma budaya poluler yang bercorak komoditas. Ritual tersebut diracik sedemikian rupa sesuai dengan prinsip perbedaan sosial dan pencapaian prestise, kelas dan status. Contohnya adalah umrah dengan artis idola, ritual tersebut ditujukan pada kelas sosial, sama halnya dengan zikir akbar dengan tema-tema khusus serta berbuka puasa yang diorganisasikan berdasarkan pada kelas sosial di dalam masyarakat, hal lainya adalah kegiatan berbuka bersama yang dilaksanakan pada sebuah hotel berbintang dan dihubungkan dengan datangnya seorang selebritas. Hal tersebut terjadi pelencengan nilai kesucian ibadah dengan adanya selebrasi ritual tersebut. Nilai akhirnya bukan kedalaman spiritual yang diperoleh, akan tetapi selebrasi keagamaan yang intim pada logika komoditi.

Keempat, simbol popular. Atau disebut dengan penampilan popular mengacuh pada penampilan yang terdiri dari nilai pakaian atau aksesoris yang mengutamakan efek kesenangan, simbol, status, tema, prestise, daya pesona sesuai dengan selera popular. Contohnya adalah menjadi peniru dari model penampilan para elit agama, di mana jenis dan model baju yang dipakai oleh para elit agama menjadi pemicu trend dan menciptakan pola hidup baru masyarakat. Modernisme dalam hal ini penyesuian Islam atau interpretasi daripemikiran Islam dalam konteks modern. Maksud dari modern adalah yang berkiblat ke barat.

Kebudayaan dapat dipahami pada 2 jenis pertama adalah kebudayaan dengan kebudayaan yang universal yaitu kebudayaan berasal dari barat yang diklaim telah mengalami universalisasi. Walaupun paradigma tersebut mengalami kontra. Kebiasaan masyarakat barat yang sering kita saksikan baik di media baik itu cara berpakaian dan mode yang telah menjadi budaya masyarakat indonesia. Dampak tersebut dapat merambat lebih cepat ke kelompok bawah akibat artis-artis di dunia hiburan yang mempunyai tingkat moderenisasi yang lebih tinggi. Dari perilaku dan gaya menjadi contoh dan di tiru karena masyakarat anggap lebih maju dan modern. Umumnya masyarakat Indonesia berperilaku mengikuti tanpa selektif sejalan dengan nilainilai ajaran agama yang di anut. Sebagian besar masyarakat merasa jika kebudayaan di negerinya sendiri dirasa jauh dari moderenisasi. Sehingga sebagian masyarakat merasa gengsi jika tidak mengikuti perkembangan zaman walaupun itu bertolak belakang dengan nilai-nilai ajaran agama dan budayanya. Dan pada akhirnya masyarakat lebih menggemari kebudayaan barat, dibandingkan dengan kebudayaan indoneisa. Dan kini nilai-nilai kebudayaan dan ajaran keagamaan semakin terkikis dikarenakan 
oleh dampak budaya Asing yang masuk ke Negara kita.

Keberadaan Budaya popular dipengaruhi oleh industrialisasi, kapitalisme dan konsumerisme. Budaya popular seringkali diperdebatkan dengan kategori lainya atau disebut dengan budaya tinggi. Hal tersebut diperdebatkan karena arti kebudayaan itu bervariasi, Menurut pendapat Ki Hajar Dewantara kebudayaan sendiri merupakan sesuatu yang memiliki keluhuran yang mengandung nilai tinggi, dan budaya popular menurut $\mathrm{Ki}$ Hajar Dewantara bukanlah budaya sebabtidak adanya unsur keluhuran, serta tidak dijunjungnya harkat, martabat, manusia. Budaya popular malah mengkondisikan masyarakat menjadi pengikut, peniru. Contohnya dibangun sebuah skema budaya dimana terdapat bintang atau superstar. Maka budaya popular mengharuskan adanya yang meniru-niru, atau harus ada pengikut atau Fans. Pengikut tersebut merupakan ciptaan dari budaya popular itu sendiri. Fans bukan hanya segelintir orang akan tetapi dapat mencapai ribuan bahkan jutaan orang. Fans inilah yang akhirnya dikondisikan menjadi peniru. Sehingga terdapat image negative pada budaya popular sebab semua lapisan masyarakat pro-aktif menjadi fans.

Sukron Abdillah, Terdapat dua hal pada budaya populer ini. Pertama, suatu budaya populer mempunyaisifat negatif sebab diproduksi secara massal dalam memenuhi kepuasan mereka yang membutuhkan dan membayarnya. Demi alasan komersial atau mendapatkan keuntungan materi, sifat negatif dari produk kebudayaan ini dimakan mentah-mentah, bahkan condong dilanggengkan. Bisnis adalah bisnis, itu kata mereka. Kedua, budaya populer memiliki akibat dan dampak yang negatif. Misalnya saat masyarakat melihat tayangan televisi atau pun video di media, masyarakat sedikit banyak terpengaruh oleh gaya yang ada pada tayangan tersebut, intinya hasil dari gaya hidup masyarakat terpengaruhi oleh prilaku hidup orang yang berbeda (2006:105).

Sisi lainnya bahwa dampak negatif dari budaya popular juga condong menjadikan masyarakat menjadi lebih hedonistik. Iklan menjadi alat untuk memuluskan jalannya kapitalisme, seringkali masyarakat telah menjadi korban iklan. Marcuse dalam John Storey berpendapat bahwa pengiklanan memicu kebutuhan palsu sebagai contoh adalah keinginan guna menjadi jenis orang tertentu, menggunakan model pakaian tertentu, mengkomsumsi jenis makanan tertentu, memakai jenis barang khusus dan lainnya (2010:145).

Masyarakat Indonesia sebagian besar mengantungkan dirinya pada bintang film atau artis penyanyi, sehingga budaya popular itu seperti terdapat wujud pemujaan pada bintang. Budaya popular mengembangkan budaya permukaan, perkara-perkara yang sifatnya dangkal yang bukan bersifat subtansial, penilaiannya adalah mereka yang dapat memerikan hiburan yang menyenangkan, para aktor yang dapat menciptakan kekonyolan. Dapat dilihat siapa sajakah yang banyak muncul di media apakah itu para intelektual akan tetapi justru merekalah yang mampu membuat kekonyolan dan kelucuan yang banyak digemari dan ditiru. Dalam budaya popular itu yang menjadi bahan penilaian adalah penampilan dan bukan sisi kecerdasan. Yang menjadi prioritas bukanlah yang cerdas dalam mencari solusi pada sebuah perkara akan tetapi adalah mereka yang mampu berbicara dengan menghibur. mayoritas semua yang diangkat adalah mereka yang memiliki popularitas, Bahkan yang muncul bukanlah mereka yang memiliki kemampuan justru mereka yang tampak dari luarnya bukan tampak dalamnya. 
Budaya popular merupakan suatu budaya kemasan, Salah satu tanda budaya popular adalah keberhasilanya dalam mengangkat sesuatu perkara yang sifatnya tidak penting, menjadi sesuatu perkara yang terlihat bagus dan penting padahal hal itu tidaklah penting, lewat provokasi, efek dan lainya. Kebudayaan apapun bentuknya akan merubah diri kita. Agama menjadikan manusia menjadi orang yang shaleh dan pada tatanan negara membentuk seseorang menjadi patuh terhadap aturan. Salah satu persoalan lain adalah manakah yang kita ikuti. Dengan semakin agresifnya budaya popular membuat masyarakat lupa pada agamanya dimana agama semakin lama semakin terabaikan.Salah satu contohnya adalah budaya merokok dimana dalam agama dihukumi makruh dan dalam pendapat lain adalah haram akan tetapi pada budaya popular justru merokok dalam iklan ditayangkan seolah menjadikan laki-laki super. Contoh lain dalam agama adalah bahwa kita dilarang untuk berlebihan akan tetapi dalam dunia live style justru kontradiktif masyarakat diminta untuk berkonsumsi berlebihan. Disinilah bawhwa budaya popular bersaing dengan agama dalam membentuk masyarakat.

Pada budaya popular terdapat yang disebut imajinasi popular, dalam budaya popular sebagian besar di sensualkan, yaitu menggunakan perempuan sebagai simboliknya. Dalam hal ini Penampilan menjadi harga mati dalam budaya popular , dan masyarakat dipaksa mengikuti model. Dalam Budaya popular tidak penting dengan tampil nalar atau logika, dan saat ini budaya popular telah masuk dalam dunia agama. Dalam budaya popular muncul seseuatu yang disebut style, fashion dan trend. Oleh karena itu ketika hal ini ada dalam dunia dakwah maka masyarakat cenderung mengikutinya tapi hanya pada aspek pakaian saja. Sehingga songkok pun menjadi trend ustad tertentu.
Hal tersebut memicu spirit populritas dan spritualitas akan tetapi yang paling ditonjolkan adalah sisi popularitas pada budaya popular juga terdapat aspek sketis yang telah merambah pada agama. Budaya popular seringkali juga mencari agama yaitu melalui tafsir dengan metode tersendiri dan berupaya mengimaninya. Sehingga memicu beberapa komoditifikasi agama, salah satunya sebut saja SQ, dimana dalam negara malaysia diprotes karena dinilai telah menjual agama. Pendekatan yang digunakan SQ adalah budaya popular. Negara mengajarkan pada masyarakat nasionalisme. Budaya popular membuat masyarakat sebagai subjek. Dan para remaja belajar dari hal itu, yang mengajarkan kepada masyarakat sesuatu yang instan. Bila masyarakat dibentuk oleh agama dibentuk melalui proses yang tidak sebentar.

Pada umumnya masyarakat kita terbuka dengan datangnya inovasi baru dalam kehidupannya, namun masyakat ternyata belum mampu memilah tentang perkara yang sesuai dan tidak sesuai dengan hukum dan norma yang berlaku di Indonesia, misalnya datangnya budaya barat kedalam kehidupan masyarakat di indonesia dapat melalui banyak metode salah satunya merupakan lewat social media. Masyarakat terbiasa melihat model fashion yang lahir dari budya barat, berawal dari gaya berbusana hingga model rambut kini masyarakat dengan mudahnya terpengaruh dengan gaya berpakaian budaya barat, berawal dari mereka yang cuma hanya melihat saja disosial media lalu menjadi ingin mencoba fashion budaya barat yang kini sedang tren. Jika di teliti lagi sebenarnya cara berpakaian budaya barat sangat bertolak dengan gaya berpakaian budaya kita yang menjunjung nilai kesopanan dan norma agama. masyarakat cenderung ingin mencoba gaya yang mereka pikir baik dan bagus untuk digunakan masyarakat dengan mudah 
terpengaruh. Kebiasaan dan pola hidup budaya barat kini seolah-olah menjadi cermin dari moderenisasi. Padahal sebenarnya hal tersebut jelas mengikis perilaku masyarakat. Dan tentu saja hal tersebut belum tentu sejalan dengan kebutuhan masyarakat kita. Keadaan tersebut terus-menerus mengikis budaya dan kearifan lokal kebudayaan masyarakat indonesia. Hal lainnya adalah bahwa nilai tradisional juga secara bertahap mengalami kepunahan sebab tidak dapat bersaing dengan budaya modern dalam wujud pergaulan masyarakat.

Dalam era globalisasi ini, jati diri bangsa Indonesia perlu dibina dan dimasyarakatkan oleh setiap warga negara Indonesia. Hal ini diperlukan agar bangsa Indonesia tidak terbawa arus oleh pengaruh dan budaya asing yang jelas-jelas tidak sesuai dan (bahkan) tidak cocok dengan bahasa dan budaya bangsa Indonesia. Pengaruh dari luar atau pengaruh asing ini sangat besar kemungkinannya terjadi pada era globalisasi ini. Batas antarnegara yang sudah tidak jelas dan tidak ada lagi, serta pengaruh alat komunikasi yang begitu canggih harus dihadapi dengan mempertahankan jati diri bangsa Indonesia, termasuk jati diri bahasa Indonesia. Sudah barang tentu, hal ini semua menyangkut tentang kedisiplinan berbahasa nasional, yaitu pematuhan aturan-aturan yang berlaku dalam bahasa Indonesia dengan memperhatikan siatuasi dan kondisi pemakaiannya. Dengan kata lain, pemakai bahasa Indonesia yang berdisiplin adalah pemakai bahasa Indonesia yang patuh terhadap semua kaidah atau aturan pemakaian bahasa Indonesia yang sesuai dengan situasi dan kondisinya.

Untuk itu perlu masyarakat pahami pula, bahwa pada budaya popular juga terdapat dampak yang positif, misalnyadalam tayangan televisi yang didalamnya terdapat siaran yang bermanfaat, dan diaplikasikan pada kehidupan. Esensinya bahwa budaya pop walaupun dinilai memiliki dampaknegatif, akan menjadi negative lagi jika disikapi dengan benar. Semuanya kembali lagi kepada masyarakat tentang seperti apa menyikapinya.

\subsection{Budaya Popular dan Degradasi nilai Agama}

Dampak merambahnya budaya popular ke dalam Islam adalah semacam banalitas agama. Di sana terdapat apa yang selama ini dianggap profan, nafsu rendahdalam pandangan Islam, saat ini menjadi bagian wacana keagamaan.Antara batas suci/rendah dan sakral/profan, saat ini dikaburkan dan digiringkearah logika budaya baru, yakni logika banalitas agama. Padaritual keagamaan, perkara yang dahulu dianggap tidak penting misalnya penampilan, gaya lelucon, gaya penampilan.Saat ini telah menjadi kebutuhan, dan mendominasi ruang dan waktu umat Islam dan menjadi rantai kehidupan keberagamaan umat Islam.

Dalam kehidupan sehari-hari sering kita jumpai para ustadz dalam acara televisi, dimana terlihat lebih mementingkan penampilannya dari pada penguasaan subtansi ajaran Islam yang disampaikanya.Banyak yang lebih mementingkan ciri khas gaya bicaradari pada esensi ajaran Islam. Inilah degradasi agama yang lebih mementingkan peterlihatan luar tanpa peduli akan makna nilai-nilai spiritualitas-ketuhanan. gaya hidup budaya popular masyarakat kini telah meminggirkan ritual keagamaan pada tempat sucinya, dan saat ini menjadi semacam ekstasi pada kondisi ketidaksadaran semu.

Agama Islam dengan penganut dua ratusan juta jiwa di Indonesia menjadi target dan komoditas yang menjanjikan dan selalu menjadi target banyak pedagang.Menurut Greg dengan kemajuan ekonomi dan melonjaknya kelas menengah dengan signifikan di Indonesia serta meningkatnya 
derajat demokrasi dan keterbukaan akses dalam informasi yang bersifat massif maka kondisi inilah yang ia sebut dengan "the turning of faith and its symbols into commodity capable of being bought and sold for profit". Inilah waktu di mana komersialisasi keyakinan sebagai usaha membuat ajaran agama atau simbolnya yang kasat mata sebagai komoditi yang dapat dikomersialkandalam meraih keuntungan.Sebelum Islam masuk di Indonesia, kapitalisme mungkintelah terlebih dahulu mengomersialisasikan ajararan agama besar dunia. Indikasi komersialisasi dapat ditandai melalui rayuan dan jaring popularmelalui iklan di banyak media massa.Kemudian juga diikuti dengan membuat produkbaru guna memenuhi kebutuhan artifisial msayarakat Muslim Indonesia. Komersialisasi mengkaburkan sudut pandang dan pola pikir masyarakat Muslim Indonesia yang akan menjelma jadi budaya popular Islam.Bagi masyarakat popular, prilaku, gaya, dan modenya akan menjadi pedomanmasyarakat. Seringkali, kepopularan tersebut dipakai dalam ekses komoditas komersil, menjadi bisnis yang menggiurkan. Sebab itulah, soalpopular itu sangat menjanjikan siapa saja, tidak hanyamilik para selebritis, akan tetapu juga menjadi incaran masyarakat umum.

\subsection{HubunganAgama dan Media}

Muchyidin Agung Harahap, Media pada perkembangannya tidak hanya menjadi entitas yang melahirkan produk budaya, ekonomi dan politik (2013:11). Akan tetapi, media sekarang initelah menjadi enitas yang membawa berbagai ideologi termasuk agama. Media baru yang tercipta dari teknologi baru sekarang ini memuat nilainilai agama baru. Dan andai diteliti lebih jauh media ternyata juga menciptakan teologi baru dalam persoalan beragama. Hampir sebagian besar masyarat mencari sumber hukum agama atau dasar teologi dari media baru. Kondisi ini semakin terlihat nyata dengan munculnya internet atau media baru. Internet membawa nilai baru padaritual beragama bagi sebagian masyarakat. Sehingga melalui kehadiran media baru itumasyarakat cenderung mengambil nilai dalam agama melalui media. misalnya adalah dengan berkembanganya media online yang bernuanasa Islam. Media ini menggunakan konten berupa ajaran Islam. Bahkan bilaseseorang yang ingin mencari referensi Al-Qur'an atau Al-Hadits cukup mengklik sebuah situs online, maka referensi tersebut akan muncul.Media baru juga mempunyai fungsi sebagai entitas dalam menyebarkan ajaran agama. Bilapada zaman dahulu seseorang yang akan menyebarkan luaskan ajaranya perlu menempuh dengan jalan kaki, maka sangat berbeda dengan kondisi saat ini. Media baru (internet) telahmenyediakan ruang dalam menyebarkan agama. Melalui situs online maka seseorang bisamenciptakanprogam penyebaran konten ajaran keagamaan. Konten tersebut dapat menembus batas ruang, waktu dan bahkan padasekat-sekat negara.

Misalnya penggunan media online atau youtube dalam menyebarkan dan berbagai video dakwah Islam. Hal ini berbeda dengan zaman dahulu dimana dakwah dilakukan melalui mimbar, dan saat ini metode tersebut telahtidak lagi efektif. Penyebaran agama Islam lebih efektif melalui pemanfaatkan media baru atau internet. Selain itu, hasilnya dapat dinikmati oleh orang lain dalam jumlah yang tidak terbatas pula. Penyebaran ajaran Islam pun dapat melewati batas negara hanya dengan hitungan detik. Hal ini menunjukkan bahwa agama dan media mempunyai hubungan yang cukup signifikan.

Berdasarkan pemaparan diatas dapat disimpulkan bahwa sekarang agama dan media memiliki hubungan yang signifikan. Perkembangan media baru (internet) iktu 
menambah keunikan hubunganantara agama dan media. Pada proses perkembangannya, justru akan terlihat bahwa media akan berubah menjadi agama bagi sebagian masyarakat. Menurut Soerjono Soekanto, Media baru tidak hanya berfungsi sebagai etintas yang memproduksi budaya, juga beralih fungsi menjadi agama/teologi baru pada tataran masyarakat (1987:157). Agama dan media adalah diskursus yang sangat menarik untuk terus dipantau perkembangannya. Media atau media massa konvensional pada mulanya berfungsi sebagai alat berkomunikasi dan sebagai saluran informasi. Pada saat itu media tidak menjadi entitas yang mempunyai sifat ideologis bagi pemakainya. Hal ini sangat berbeda dengan media massa yang telah meningkat saat ini, dimana saat ini memiliki kepentingan ideologis dan juga politis. Media massa mempunyai hubungan timbal balik dengan masyarakat. Karena media membutuhkan kehadiran masyarakat, dan sebaliknya masyarakat membutuhkan kehadiran media baru.

Munculnya media baru (internet) dengan media sosial sebagai turunannya, budaya masyarat berubah menjadi lebih dinamis. Komunikasi yang pada awalnnya hanya terbatas, sekarang ini cenderung tidak terbatas. Dengan internet, seseorang dapat melakukan komunikasi dengan orang lain yang berada di benua lain. Proses komunikasi dilakukan dengan sangat mudah tanpa terhalang oleh waktu dan sekat negara. Media baru berkembang menjadi piranti yang memiliki efek global. Media baru membawa kebebasan berkomunikasi bagi masyarakat dunia. Majunya media komunikasi dengan piranti media sosialnya menciptakan relatias baru dibandingkan dengan sebelum munculnya media sosial kencenderungan di era media ciber. Media sosial yang membuat era media ciberadalah ranah komunikasi massa yang akan terus berkembang secara dinamis. Dalam Era media siber telah membuat budaya baru pada sebagian masyakarat pengguna internet. Para pengguna internet memanfaatkan jejaring sosial sehingga menciptakan komunitas dan budaya popular yangcenderung baru.

Pada mulanya media berfungsi sebagai media penyambung pesan, media hiburan dan sebagai kontrol sosial. Peran media pada mulanya berfungsi sebagai bagian dari demokrasi yang turutmengawasi tugas pemerintahahan. Sekarang ini, justru media berfungsi sebagai alat guna melanggengkan kekuasaan. Media menggunakan hegemoninya guna memperkuat kekuasaan pemerintah. Media tidak pernah mempunyai sifat netral dalam berbagai bidang sebab media bukan ruang yang vakum. Media akan mempunyai dua kepentingan yang terhubung dengan ideology penggunanya.

Media baru dengan media sosial mempunyai keterkaitan yang kokoh dengan agama. Informasi yang disebarkan melalui media bukan hanya dalam bidang sosial budaya, ekonomi dan politik. Justru, sekarang sangat mudah untuk menemukan berita yang berhubungan dengan agama. Media kini menjadi ruang publik yang amat bebas untuk menafsirkan berbagai ajaran keagamaan. Misalnya adalah banyaknya media online yang menggunakan pendekatan ajaran agama Islam. Media tersebut memang hadir dengan berbagai karakter dan bentuk.

Media dalam konteks media dan agama dapat dipahami baik secara terfokus dan spesifik atau dengan menggunakan metode yang lebih luas serta diskursif. Maksudnya adalah memahami perbedaan itu menjadi sangat penting dalam membuat definisi mengenai perkembangan studi media dan agama. Sehingga, agama membutuhkan mediaguna disebarkan pada masyarakat. Akan tetapi, penyebaran itu memicu kasus baru bahwa sesuatu yang direpresentasikan 
oleh media merupakan bukanlah relaitas sebenarnya.

Misalnya media Islam tidak semua selalu mewakili atau merepresentasikan nilai Islam. Media itu terkadang hadir hanya untuk mewakili kelompok tertentu dan tidak dapat menjadi referensi nilai ajaran Islam yang terpercaya. Media menghubungkanpesan yang berisi tentang nilai-nilai Islam, akan tetapi representasi maknanya menjadi samar. perkara yang direpresentasikan oleh media adalah relalitas yang dikonstruksi seolah-olah menjadi fakta. Sehingga, masyarakat memahami pesan-pesan agama dengan metode yang berbeda. Otoritas keagamaan menjadi tidak terkontrol dan mengarah pada bentuk yang libertarian.Agama Islam telah memiliki ajaran yang telahbaku, dengan makna yang universal. Ada beberapa modeldalam menafsirkan ajaran agama Islam. Hal tersebut dilakukan agar Islam tidak dipahami dengan metode yang keliru, sehingga ajaran Islam tidak berubah hingga akhir zaman. Menafsirkan ayat Al-Quran atau hadits mesti melalui tahapan yang penuh kehati-hatian dan tidak sembarangan. Sehingga, ajaran Islam tidak akan mengalami distorsi pemaknaan.

Hadirnyamedia baru memicu beberapa persoalan bagi penyebaran informasi ajaran agama Islam. Media baru adalah realitas yang tidak mengenal batas ruang dan waktu. Sehingga, sesuatu yang disebarkan pada media baru tidak selamanya berbanding lurus dengan fakta di dunia nyata. Agama dalam media menjadi sesuatu yang bisa saja menjadi terdistorsi. Agama yang ada di media bukan merupakan hakikat agama yang sejatinya. Perdebatan ini akan terus muncul sejalandengan perkembangan media baru saat ini. Media membutuhkan agama menjadi bagian dari komoditas ekonomi.Agama adalah praktik pengimanakepada Tuhan Yang Esa dan bukanya dari produk budaya. Media baru membawa metode baru dalam ritual beragama. Agama bagi sebagian masyarakat hanya ditentukan dari hasil budaya melalui media. Artinya adalah ketika media baru memiliki hubungandengan ritual agama yang dilakukan oleh masyarakat. Bila praktik agama hanya dilahirkan dari hasil produk budaya media, maka agama akan menjadi kurang sakral. Praktik agama ini akhirnya akan lebih mengarah pada wujud pluralisme agama.

Media dalam perkembangannya adalah entitas yang melahirkan berbagai produk budaya. Misalnya adalah budaya yang dilahirkan oleh media adalah metodea berkomunikasi masyarakat. metode berkomunikasi ketika internet masih belum muncul akan berbeda dengan metode berkomunikasi ketika internet telahmuncul. Bahkan, ketika era media siber lahir, budaya yang dihasilkan telah mengalami perubahan. Maksudnya adalah bahwa budaya pada masyarakat akan selalu dinamis sejalandengan perkembangan media. Ada liabilitas (timbal balik)antara perkembangan media dengan budaya. peran media sebagai agama lahir saat ditemukannya mesin cetak pertama kali. ketikaitu kitab suci semisal injil kemudian dikodifikasi melalui kertas. Sebelumnya media penulisan injil hanya menggunakan tulang, batu, kulit, papirus dan lain-lain. Media ituhakikatnyadapat dipilah bahwa media sebagai agama. Sejarah menunjukan bahwa agama diajarkan lewat berbagai media. Semenjak era pramasehi, media yang dipakai memang masih sangat sederhana. Artinya, sepanjang sejarah media tersebut memang telah memiliki hubungan timbal balik dengan agama.

Kondisi tersebut memiliki kemiripan dengan apa yang terjadi dengan agama Islam. Pada awalnya, Al-Qur'an diturunkan melalui malaikat Jibril kepada nabi Muhammad SAW. Al-Qur'an dibacakan pada Muhammad lalu dihafal. lalu Al-Qur'an 
ditulis oleh para sahabat. Proses Penulisan Al-Qur'an juga masih menggunakan media yang sederhana contohnya tulang hewan, batu, kulit, pelepah kurma dan lainya. walaupun, Al-Qur'an masih tetap dihafal oleh para hufadz (penghafal Al-Qur'an) guna tetap menjaga keasliannya.

Keterkaitan antara media dan agama adalahbahwa sebagian masyarakat menggunakan media sebagai rujukan ritual keagamaan. Agama adalah praktik penyembahan pada Tuhan, dan agama bukan produk budaya. esensi agama ini yang perlu dipahami oleh pengguna media. Karena jikatelahdipahami maknanya agama maka akan lebih mudah dalam memberikan penjelasan manfaat media untuk ritual keagamaan.Media sendiri merupakan entitas yang dimanfaatkanguna menyebarkan luaskan informasi. Sehingga informasi mengenai ritual keagamaan adalah ragam informasi dapat menjadi bagian dari informasi media. Akan tetapi, media bukanlah entitas yang hadir dalam ruang bebas. Ketika informasi diciptakan oleh media, akan ada faktor sosial yang mendukung. Informasiyang diciptakan oleh media tidak selalu selaras dengan fakta yang sebenarnya. Informasi diciptakanlalu disalurkan lewat perantara. Sehingga, sering terjadi distorsi fakta ketika informasi dikonsumi oleh masyarakat.

Media baru yang muncul dengan media sosial melahirkan ragam informasi yang lebih komplek. Dengan muncul berbagai situs dengannama agama. Bahkan, Media sosial juga banyak melahirkan praktik yang sama. Banyak kontenajaran keagamaan yang datangmelalui media sosial. Kondisi ini digunakan oleh masyarakat dalam mencari informasi tentang keagamaan.Ada beberapa perubahan secara radikal pada ritual keagamaan dalam beberapa masyarakat. Dimana masyarakat lebih nyaman mencari informasi keagamaan lewat media sosial yang ada. Ada semacam keterkaitan antara media dan masyarakat agama. Maksudnya adalah bahwa media dalam beberapa konteks yang terjadi memang telah dijadikan agama oleh masyarakat. Media melahirkan teologi baru bagi sebagian masyarakat. Kondisi tersebut akan terus berubah mengikuti perkembangan media itu sendiri. Media melahirkan produk budaya yang justru dipahami sebagai agama oleh masyarakat.

\section{Simpulan}

Suatu budaya dapat menjadi populer lewatmedia sebagai bagian dari proses kapitalisme. Kebudayaan yang populer seringmengikis agama dan budaya lokal masyarkat.Keberadaan Media akan selalu berkembang yang berjalan secara dinamis mengikuti alur perkembangan teknologi informasi. Budaya yang dihasilkan dari media tersebut akan berubah juga secara dinamis. Banyak distorsi fakta yang dilahirkandari media yang menimbulkan dampak positif dan negatif. Selain itu dalam konteks agama sejatinya media dan agama memiliki hubungan yang siginifikan. Keterkaitan antara media dan agama adalah bahwa sebagian masyarakat menggunakan media sebagai rujukan ritual keagamaan. Agama adalah praktik penyembahan pada Tuhan, dan agama bukan produk budaya. Itulah esensi dari keberadaan agama yang perlu dipahami oleh masyarkat pengguna media. Karena jika sudah dipahami maknanya,maka agama akan lebih mudah dalam memberikan penjelasan manfaat media dalam praktek keagamaan.

\section{Daftar Pustaka}

Abdillah, S. (2006). Hidup Sehat ala Punk Hardcore. Bandung : Mizan.

Harahap, M. A. (2013). Kapitalisme Media:

Ekonomi Politik Berita dan Diskursus Televisi, cet ke-1. Yogyakarta: Pustaka Aura. 
Jalaluddin. (1996). Psikologi Agama. Jakarta : Raja Grafindo Persada.

Moeljono, D. (2006). Budaya Organisasi dalam Tantangan. Jakarta: PT Elex Media Komputindo.

Soekanto, S. (1987). Sosisologi Suatu Pengantar, cet ke-8. Jakarta: CV Rajawali.

Storey, J. (2010). Cultural Studies dan Kajian Budaya Pop. Yogyakarta: Jalastura.

Widiastono, T. D. (2004). Pendidikan Manusia Indonesia, (ed.), Jakarta: Kompas. 